\title{
Rozvoj vnitřní motivace ke sportování u dětí školního věku \\ se zaměřením na pozitivní prožitky
}

\section{Development of intrinsic motivation through satisfaction with physical activities of school-aged children}

\author{
Adam Blažej \\ Fakulta sportovních studií, Masarykova univerzita, Brno
}

\begin{abstract}
Abstrakt
Článek se zabývá rozvojem spokojenosti a pozitivních prožitků ze sportovních tréninků, které děti školního věku navštěvují, a jejich vlivem na vnitřní motivaci. Autor popisuje prístupy a metody trenérů k navození takové vzpomínky jedince z tréninkové jednotky, která zvýši pravděpodobnost vytvoření pozitivních prožitkư z ní. To má často za následek i rozvoj vnitřní motivace $k$ výkonu a potřebu rozvíjet se v daném sportovním odvětví. Existuje několik teorií o rozvoji vnitřní motivace a pozitivních prožitků z různých oblastí lidského bytí. Ty jsou v článku podrobněji popsány, pričcemž je uvedeno také několik přikladů o jejich využití ve sportovní praxi. Článek je tedy primárně postaven na přehledu teorií z jiných věd a oborů (psychologie, pedagogika) aplikovaných do kinantropologie, respektive do sportovního tréninku, které jsou při zvyšování spokojenosti a následném rozvoji vnitřní motivace efektivní.
\end{abstract}

\begin{abstract}
This article deals with the development of satisfaction and positive feelings and their effect on intrinsic motivation of children participated in physical activities. The author describes some attitudes and methods of trainers which could result to evoke such memories from training session that increases the possibility of creating a positive experience out of it. Which often results into an increase of intrinsic motivation to exercise and need of development in that physical activity. There are several theories about the development of intrinsic motivation and satisfaction of various areas of human being. These are described in detail in the article which includes some examples of their use in sport practice. The article is therefore primarily based on a survey of the theories of other sciences and disciplines (psychology, pedagogy) and their application to kinesiology.
\end{abstract}

Klíčová slova: tělesná výchova, pohybová aktivita, motivace, vnitřnímotivace, spokojenost, pozitivní prožitky.

Keywords: physical education, physical activity, motivation, intrinsic motivation, satisfaction, positive feelings.

\section{CHARAKTERISTIKA PROBLÉMU}

Motto: Úspěch není klíčem ke spokojenosti. Spokojenost je klíčem k úspěchu. Pokud děláš to, co miluješ, budeš úspěšný. Albert Schweitzer

Na základě několika teorií a výsledků studií (Charlton \& Winsler, 1998; Ryan, R., Frederick, C., Lepes, D., Rubio, N. \& Sheldon, K., 1997; Pano \& Marcola, 2012) je známo, že za rozvojem vnitřní motivace nejen dětí v jakémkoliv sportovním odvětví stojí především touha soutěžit a existence pozitivních prožitků při vykonávání dané sportovní aktivity. A jakkoliv je i touha soutěžit u jedinců mladšího a staršího školního věku relativně dobře manipulovatelná, mnohem lehčí je pro trenéry 
uzpůsobit své tréninky tak, aby si z nich dítě odneslo pozitivní vzpomínky. Právě kladný postoj ke sportovní aktivitě je silným determinantem, který ovlivňuje vnitřní motivaci. Touha soutěžit je totiž častokrát snižována i neadekvátní výchovou dětí ze strany rodičů, kteří např́íklad neustálým oceňováním dětí vnějšími stimuly (hmotné odměny) zesilují závislost na těchto odměnách, a samotná touha soutěžit či vítězit vycházející z nitra dítěte je tak nevědomě potlačována (Deci \& Ryan, 1985). Pozitivní vzpomínky s cílem vyvolat či zvýšit vnitřní motivaci jsou z pohledu trenéra mnohem jednodušeji dosažitelné. Řada trenérů však svým přístupem jak k tvorbě tréninkových jednotek, tak i k samotným dětem spokojenost (ani touhu soutěžit) nevyvolává, a děti své sportovní tréninky navštěvují, aniž by měly pádný důvod, proč tak činí.

Dủležité je třeba také uvědomit si, že motivační struktura u dětí školního věku se diametrálně odlišuje od motivační struktury adolescentů či dospělých sportovců. Zatímco dospělí profesionální sportovci se na základě kognitivní motivace dokážou rozhodnout pro výkon dané sportovní aktivity na základě odměny v podobě finančních prostředků, třebaže je už aktivita samotná nenaplňuje, dítě tímto uvažováním ještě neoplývá, a přinejmenším z dlouhodobého hlediska by jeho participace byla neudržitelná. Jak tvrdí Biddle, Wang, Chatzisparantis a Spray (2003), nejsilnějším motivem pro participaci v dané sportovní aktivitě u dětí a mladistvých $\mathrm{v}$ letech od jedenácti do devatenácti je potěšení z vykonávání této aktivity. Opačný efekt pak pochopitelně bude mít negativní emoční prožitek, který bude posilovat tendenci se aktivitě vyhnout (Vágnerová, 2005).

Nejjednodušší přístup, který by v dětech vyvolal požadovanou dávku spokojenosti, je pochopitelně tvorba tréninků formou her. To je bezesporu pravda, nicméně řada trenérů pravděpodobně oprávněně odmítá vytvářet tréninkový program pouze na základě cvičení formou her, jelikož by progres dětí nebyl při tomto typu tréninků tak dynamický. Existuje však mnoho postupů, př́istupů a metod, kterými lze docílit jak dynamického rozvoje, tak také rozvoje vnitřní motivace prostřednictvím pozitivních prožitků získaných na trénincích. Na spokojenost s vykonáváním sportovní aktivity má bezesporu kromě tréninku formou her a jiných aspektů také velký vliv psychologické působení a osobnost trenéra - ta je však téměř nezměnitelná. Tento článek se proto zaměřuje na nejjednodušeji transformovatelnou složku tréninkových jednotek - ovlivňování a podtržení významu vnitřní motivace jedince mladšího a staršího školního věku prostřednictvím získání pozitivních prožitků na těchto trénincích. Výsledkem souhrnu teoretických východisek pak bude přehled použitelných návrhů při pohybových aktivitách jedinců v první etapě motivační struktury v praxi.

\section{EMOCE VE SPORTU}

Z evolučního hlediska lze tvrdit, že emoce jako takové vznikly proto, aby efektivně koordinovaly naše odlišné systémy reakce (fyziologický, prožitkový, výrazový), a pomohly nám tak reagovat na důležité výzvy nebo prŕiležitosti v prostředí (Levenson, 1994; in Stuchlíková, 2007). Dle Slaměníka (2011) pak v současné psychologii převládá názor, že každou emoci lze považovat za jedinečnou a charakteristickou jejími prožitkovými, fyziologickými, behaviorálními a sociálními znaky, které jsou vyvolány specifickými podněty a událostmi. Je zaznamenáno, že průběh a vznik některých emocí má stejný scénář, prričemž jiné lze z tohoto pohledu považovat za unikátní (za typický příklad takové emoce můžeme považovat úzkost). Množství těchto pohledů však značně komplikuje samotné definování emoce, což mnohokrát způsobuje nejasnost a ústí v různorodost výsledků studií s touto tematikou. $Z$ pohledu sportovního trenéra jsou však emoce, které dokáže u svých svěřenců vzbudit, kruciální, protože především on sám je nositelem událostí a podnětů, jejichž důsledkem bude vznik určité emoce. Především na něm a na jeho prŕístupu $\mathrm{k}$ tréninkům 
a dětem závisí druh a intenzita emoce, kterou si dítě z tréninkové jednotky odnese, načež tato emoce bude hrát klíčovou roli v pozdější participaci dítěte na dané sportovní aktivitě.

Členění emocí nejen ve sportu je velmi komplikované, a to už jen z důvodu stále nedokonalého definování pojmu emoce. Existuje tak nepřeberné množství pohledů, jimiž lze emoce klasifikovat. Pro potřeby trenéra či učitele tělesné výchovy za nejzákladnější pohledy lze považovat následující:

1. Z hlediska vlivu emoce zkoumaného subjektu na ostatní subjekty na intrapersonální, interpersonální a intraskupinové emoce (Hanin, 2012).

- Intrapersonálními faktory rozumíme takové, které ovlivňují vnímání pouze jedné dané osoby, a to ve vztahu jedince $\mathrm{k}$ prostředí. V praxi za takovéto faktory považujeme např́klad úzkost nebo potřebu úspěchu založenou na vnitřní motivaci.

- Interpersonálními a intraskupinovými faktory jsou ty, jejichž přítomnost u jedince ovlivňuje postoj, chování či emoce ostatních (Hanin, 2012).

2. Z hlediska vlivu na způsob chování a projev v rámci dané aktivity Jansa a kol. (2012) rozlišuje stenické a astenické emoce:

- Stenické emoce činnost prohlubují, posilují a povzbuzují jedince k výkonu činnosti, přičemž Hanin (2012) dodává, že jsou pro jedince nápomocné, prospěšné a participaci na dané aktivitě usnadňují.

- Astenické emoce ji naopak tlumí. Mezi typické příklady astenických emocí patří například hněv, vztek nebo strach. Je pro ně charakteristické, že jsou z pohledu jedince vysilující.

- Hanin (2012) ještě rozlišuje emoce neutrální, pro něž je charakteristické, že nemají na vnímání jedince a jeho chování žádný dopad.

Podobné členění také klasifikoval Seligman (2002), který užil termíny pozitivní a negativní emoce. Pro potřeby participace a případného rozvoje a zdokonalování se v jakémkoliv sportovním odvětví lze za velmi důležitý emoční stav považovat motivaci.

\section{VNITŘNÍ MOTIVACE}

Motivace je chápána jako proces, který determinuje sílu, zaměření a trvání chování, přičemž je častokrát spojována se stavem nedostatku označovaným jako potřeba. Obecný princip motivace pak lze vyložit jako maximalizaci př́ijemného a minimalizaci nepř́ijemného a udržování psychické rovnováhy (Nakonečný, 1999).

Nejrozšířenější teorií z oblasti motivace je Maslowova pyramida potřeb, která, jak už název napovídá, vychází z čistě vnitřních pobídek (potřeb). Od vytvoření této tradiční pyramidy však uplynulo již více než sedmdesát let, a tak byla častokrát jinými autory transformována (Kenrick, Griskevicius, Neuberg \& Schaller, 2010). Maslowova pyramida potřeb pak bezpochyby správně reflektuje fáze a důležitost lidských potřeb, nicméně je velmi zjednodušuje, a proto musí být pro správnější pochopení motivační struktury doplněna i jinými teoriemi. Řada autorů (Deci, Hayamizu) ve svých studiích potvrzuje, že tzv. dokonalé motivační schéma by mělo být tvořeno jak vnitřními, tak částečně také vnějšími pobídkami, přičemž je třeba mít na paměti, že Maslowova pyramida potřeb respektuje pouze dlouhodobý horizont, nikoliv krátkodobý. V krátkodobém horizontu totiž člověk nemusí nutně uspokojit potřeby z nižších pater pyramidy, aby uspokojil např́klad touhu po seberealizaci (její dosažení je naopak častokrát podmíněno potlačením potřeb z nižších pater Maslowovy pyramidy).

Pro potřeby práce s motivací je tedy třeba pochopit rozdíl mezi vnitřní a vnějš́ motivací. Zatímco vnější motivace je soubor pobídek, které nabádají k vykonávání činnosti pouze na základě dosažení kýženého výsledku, vnitřní motivace vytváŕí touhu k provozování aktivity z radosti jako 
takové. Vnitřně motivovaná osoba je tedy pobízena $\mathrm{k}$ výkonu určité aktivity pro potřebu bavit se či soutěžit, na rozdíl od externě motivované osoby, jejímiž motivy k výkonu určité činnosti jsou odměny, výhružky nebo tresty. U lidí tedy není interní motivace jediným druhem, nicméně se považuje za neoddělitelnou a především jednu z nejdůležitějších. Už od narození jsou zdraví lidé aktivní, zvídaví a hraví a vykazující ochotu učit se a zkoumat, přičemž všechny tyto prvky lidského bytí včetně touhy po soutěžení lze považovat za základní (vnitřní) psychologické potřeby. Z tohoto důvodu lze předpokládat, že nadbytečné množství vnější motivace není potřeba. Interní motivační tendence jsou tedy klíčovým prvkem v kognitivním, společenském, ale i tělesném rozvoji, a je tak ve vlastním zájmu jedince rozvíjet své dovednosti a schopnosti v uvedených aspektech osobního rozvoje (Ryan \& Deci, 2000). Ve sportovním prostředí je charakteristickým znakem vnitřní motivace pocit zadostiučinění $\mathrm{z}$ předvedeného výkonu.

Mnoho lidí však z ne zcela jasných důvodů absolutně rezignuje na jakoukoliv zodpovědnost za své činy a jejich touha po rozvoji v jakékoliv oblasti jejich bytí (nejen ve sportu) je v podstatě vymazána, či potlačena. Důvody pro dlouhotrvající sezení před televizními obrazovkami, netrpělivé čekání na víkend a absence jakékoliv aktivity v průběhu dne nejsou zatím zcela zjevné. Rozdíly mezi takovými lidmi a těmi, již jsou vnitřně motivovaní, jsou pak evidentní především v těchto aspektech: zájem a nadšení, sebevědomí vedoucí ke zvýšení výkonu a kreativity (Deci \& Ryan, 1991; Sheldon, Ryan, Rawsthorne, \& Ilardi, 1997), nižší „drop-out“ v rámci dané aktivity a obecně ve zvýšené kvalitě života (Ryan, Deci, \& Grolnick, 1995; in Ryan, Richard, Deci \& Edward, 2000).

Kromě interní a externí motivace je nedílnou součástí motivačního spektra také stav zvaný amotivace. Tu ve své práci klasifikovali Deci a Ryan (1985) a vymezili jednotlivé typy a fáze motivace.

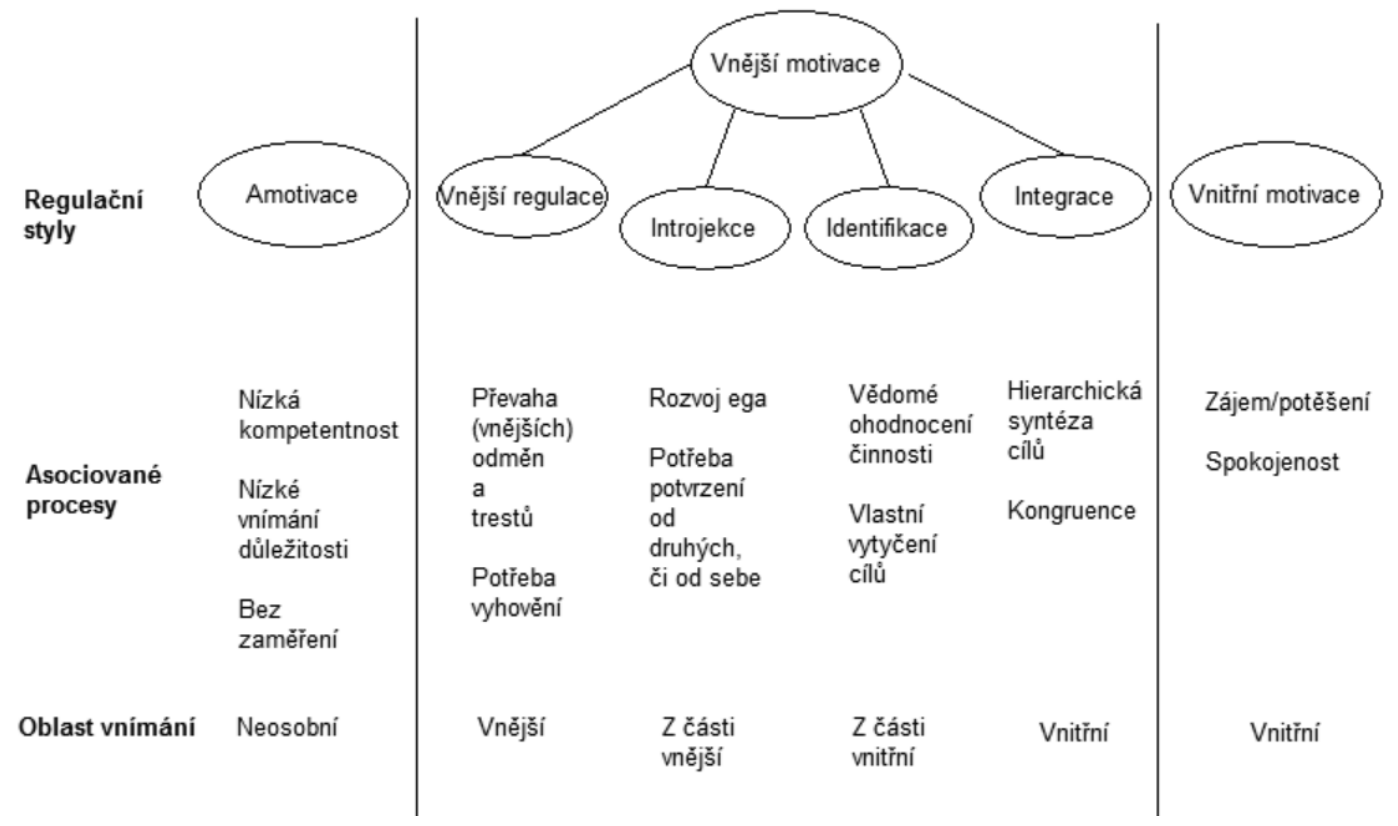

Obr. 1: Klasifikace lidské motivace (Deci \& Ryan, 1985)

Zmíněná amotivace se nachází na levém konci grafu č. 1. Jedná se o stav, kdy jedinec vykazuje žádné či minimální známky zájmu o činnost a nekompetentnost pro výkon činnosti. Vzhledem $\mathrm{k}$ pohybu coby přirozené potřebě člověka, by se však tento prvek neměl v prostředí pohybových aktivit vůbec objevovat. Napravo od amotivace se nacházejí různé stupně motivace, které se liší podle míry autonomie či odhodlání k výkonu činnosti. 
Do oblasti motivace, v níž jedinec využivá čistě vnitřní pobídky, se dle Deciho a Ryana (2000) zařazuje styl integrace a vnitřní motivace. Prvek integrace se vyskytuje u jedinců vykonávajících aktivity, které jsou přizpo̊sobeny jejich potřebám a hodnotám, s nimiž jsou zcela kongruentní a za jejíž výsledky či důsledky přebírají zodpovědnost (Deci, Eghrari, Patrick a Leone, 1994). Na podobných základech je položena také vnitřní motivace, nicméně u ní můžeme zaregistrovat také bezmezné odhodlání jedince $\mathrm{k}$ výkonu činnosti bez ohledu na množství a velikost překážek, které by výkonu této činnosti bránily. Tento stupeň v podstatě popisuje stav, kdy jedinec vykazuje takové tendence, které jej nutí k seberozvoji, jenž je v jeho případě základní psychologickou potřebou (in Ryan, Richard, Deci \& Edward, 2000). Podobné členění lidské motivace prosazují také Ryan a Connel (1989), kteří však schéma motivace rozdělili do pouhých čtyř etap: vnější motivace (1), introjekce (2), identifikace (3) a vnitřní motivace (4). Tyto fáze svými charakteristikami odpovídají popisu totožných fází Deciho a Ryana (1985). Fázi introjekce (2) však doplňují o fakt, že zdroj kontroly nad výkonem činnosti vychází z nitra, a jako příklad této fáze uvádějí studenta, který se před zkoušku učí z toho důvodu, aby se pak necítil vinným, že se nepřipravil (in Hayamizu, 1997). Deci a kol. (1994), jak už bylo řečeno, považují v této fázi za charakteristický fakt, že jedinec danou činnost nepřijímá za svou, neidentifikuje se s ní, nicméně přijímá hodnoty, které s sebou nese. A právě hranice mezi introjekcí a integrací a její překlenutí bývá častokrát zlomovou nejen při participaci na sportovních aktivitách.

S vnitřní motivací je velmi úzce spjat pojem kognitivní motivace - rozumové zhodnocení situace a záměrné definování určitého cíle, jehož splnění přinese v budoucnu uspokojení. V tomto prrípadě je motivace ovlivňována minulou zkušeností, která se projevuje v konkrétní představě cíle, jeho obsahu, ale i ve zhodnocení míry jeho dosažitelnosti. Tímto způsobem modifikuje zkušenost vznik nových motivů i volbu chování, které jedinec v dané situaci považuje za nejvýhodnější. Tento druh rozumového zhodnocení a především jeho dlouhodobého udržování je však vidět ve věkové kategorii školního věku zřídkakdy. Za schopnost chtění, vědomého určení cíle a vynaložení úsilí zaměřeného na jeho dosažení, jakkoliv toto úsilí může být nepř́ijemné či bolestivé, lze považovat také pojem vůle. Pro ni je charakteristické, že jde častokrát proti biologickým a psychickým potřebám jedince. Volní jednání pak často bývá navozeno potřebami vy̌šsího řadu, za což lze považovat na základě Maslowovy pyramidy potřeb například potřebu uznání či seberealizace (Vágnerová, 2005). Jak už ale bylo zmíněno, prvky kognitivní motivace či vůle jsou přinejmenším u dětí školního věku registrovatelné zřídkakdy.

Na základě experimentálního výzkumu (Deci, 1971), v rámci kterého byla účastníkům udělena „svobodná volba“ pro vykonání dané činnosti, se prokázalo, že participanti, kteří byli ušetřeni jakýchkoliv vnějších podnětů k výkonu činnosti, trávili u vykonávání daného úkolu více času než skupina, která byla vnějšími motivy pobízena. Tyto výsledky však značně zjednodušují motivační tendence, jelikož každý jedinec se může nacházet v jiné etapě motivační struktury. S výsledky tuto problematiku silně posunujícími kupředu přišel ve své studii Hayamizu (1997), který podrobil zkoumání vliv vnějších a vnitřních pobídek na již zmíněné čtyři fáze motivačního schématu (vnější motivace, introjekce, identifikace a vnitřní motivace). $Z$ výsledků bylo patrné, že čím více jsme se ve schématu posunovali směrem $\mathrm{k}$ vnitřní motivaci, tím menší vliv měly na jedince vnější pobídky. Jejich efekt naopak silně rostl s fází vnější motivace. Na základě těchto faktů je z pohledu trenéra důležité rozpoznat, v které fázi motivačního schématu se je jeho svěřenec nachází, a dle toho volit pobídky a celkový přístup. V téže studii bylo rovněž zmíněno, že jedinci, kteří se nacházeli spiše v prvních dvou fázích schématu a byli spiše motivování vnějšími pobídkami, v případě neúspěchu měli častěji tendenci svádět tento neúspěch na vnější přičiny. 


\section{MOTIVAČNÍ STRUKTURA SPORTOVCE}

Především u dětí školního věku ovlivňují participaci na pohybových aktivitách dva aspekty: touha soutěžit a zažívání pozitivních prožitkủ z pohybové aktivity (Charlton \& Winsler, 1998). Právě tyto dva aspekty jsou základním stavebním kamenem vnitřní motivace, na rozdíl od odměn či trestů, které podporují motivaci vnější. $Z$ pohledu trenérů je zřejmé, že by měli respektovat strukturu motivačních tendencí jako celek, tedy zakomponovat i pobízení dětí k výkonu odměnami či tresty. Nicméně stěžejním prvkem, na němž participace dětí na pohybových aktivitách stojí, by měla stále být motivace vnitřní. Ta však může vzniknout kdykoliv v průběhu života $\mathrm{z}$ vnějších pobídek. U řady dospělých totiž bylo zaznamenáno, že jejich motivy $\mathrm{k}$ výkonu pohybové činnosti (v tomto prípadě navštěvování fitcenter) byly čistě vnější (uznání okolí, pochvaly směřované k atraktivitě jejich těla), nicméně postupem času se přechýlily do fáze vnitřní motivace, při níž danou pohybovou aktivitu jedinec dělá proto, že jej baví, respektive že se v ní chce zlepšovat (Ryan, Frederick, Lepes, Rubio \& Sheldon, 1997). Tento fakt tedy potvrzuje nutnost pohledu na strukturu motivačních tendencí jako na celek, který je tvořen celou řadou komponentů.

Při práci s dětmi školního věku se zaměřením na motivaci je však třeba mít na paměti, že jejich motivační struktura se diametrálně liší od struktury jiných věkových kategorií. Obecně se uvádějí čtyři fáze vývoje motivační struktury:

1. generalizace motivační struktury,

2. diferenciace motivační struktury,

3. stabilizace motivační struktury a

4. involuce motivační struktury.

Pro potřeby trenérů a učitelů dětí školního věku je klíčová především generalizace motivační struktury a počátek druhé fáze, tedy stabilizace motivační struktury. V generalizaci (1) motivační struktury se projevuje především vliv rodičů, protože to jsou nejčastěji oni, kteří svému potomkovi vyberou př́slušný sport. Nejčastějším důvodem pro danou volbu bývá blízkost sportoviště k bydlišti či doporučení známých a kamarádů. Zájem mladého sportovce o daný sport je pravděpodobně i proto nestálý a nejdůležitějším motivačním faktorem se stává libost či nelibost provozované činnosti. Ve fázi diferenciace (2) mladí sportovci začínají diferencovat svůj vztah k danému sportu na základě úspěchu a neúspěchu. Jsou-li v činnosti zdatní a jejich výsledky jsou nadprůměrné, tvoři to poměrně trvalý základ motivační struktury. I proto by trenéři měli dbát na správný prístup k případným porážkám, kteří jejich svěřenci při své činnosti zaznamenají. $V$ tomto věku nakonec vzniká dominantnější zaměření na určitý sport. Stabilizace (3) motivační struktury nastává v okamžiku, kdy silnou účinnost získají soutěžní motivy, sebeuplatnění či sociální postavení. Sportovec už má tedy i jiné cíle, než je pouhá radost z pohybu (finance, sláva apod.). Poslední fází v motivační struktuře sportovce pak je involuce (4). Do popředí se v této fázi dostávají takové motivy, jako je například sportování bez většího zaměření na výkonnost. $Z$ psychologického hlediska je interesantní, že takto motivovaní sportovci mívají relativně velké úspěchy, často větší než dřive. Jsou totiž zbaveni pocitu nadměrné zodpovědnosti, a proto se jim i lépe závodí (Vaněk a Hošek; in Hošek, Slepička a Hátlová, 2006). Objektem zájmu tohoto článku jsou však pouze první dvě fáze.

Teorie motivační struktury se však nejevila jako úplná, respektive nereflektovala několik aspektů. Mezi nimi např́klad výkonnostní úroveň sportovce (rekreační sportovec $\times$ profesionál), jeho motivy či roli sociálního prostředí, v němž se sportovec pohybuje (přístup rodičů, trenérů, klubu, státu). Z toho důvodu byla pak tato teorie motivační struktury mnoha jinými autory (Vallerand a kol.; Wylemann \& Lavallee; Stambulova a kol.; Bloom) transformována na tzv. teorii transition, která se zaměřuje především na přechody mezi jednotlivými fázemi - at už z důvodu častého drop-outu mezi prvními dvěma fázemi či na přechod do fáze involuce z hlediska návaznosti 
na tzv. duální kariéru. Teorie transition na rozdíl od klasického modelu motivační struktury může být aplikována nikoliv pouze z pohledu výkonu či úrovně schopností, ale také z pohledu motivace, či vlivu sociálního prostředí (in Válková, 2016).

Wylleman, Lavallee \& Alfermann (1999) identifikovali jednotlivé přechody (transitions) následovně:

1. Začátky sportovní specializace - jsou determinovány především požadavky jednotlivých sportů (např. požadavky na zvládnutí pohybových úkonů) a trenéra. $Z$ toho důvodu je důležité, aby si mladí sportovci zvolili pro sebe správný sport tak, aby je bavil a mohli v něm ukázat své kvality.

2. Přechod k výkonnostnímu sportu - charakterizuje potřeba sportovce nalézt způsob, jak se vypořádat $\mathrm{s}$ tlakem, který na něj naložila náročnost soutěže a soupeři, spoluhráči nebo trenér. K zvládnutí tohoto přechodu se stále více zdůrazňuje mentální vybavení sportovce. V této fázi často dochází ke změně jeho životního stylu.

3. Přechod $\mathrm{z}$ amatérské roviny do roviny profesionální - je charakterizován přizpůsobením se sportovce na speciální profesní požadavky sportu (tréninkový režim apod.)

4. Přechod z vrcholu kariéry k jejímu konci - vyznačuje se hledáním dalších možností, jak na vrcholu kariéry setrvat, a př́ipravou na opuštění sportu.

5. Ukončení sportovní kariéry - je charakterizováno změnou povolání a životního stylu. (Jde o dramatické změny, častým úkazem je nezvládnutí tohoto přechodu).

K orientaci o motivaci jedince je třeba znát strukturu jeho motivačních tendencí. Ta je u každého sportovce jiná, přičemž ji významně ovlivňuje především stupeň výkonnosti sportovce a jeho věk. Strukturu motivačních tendencí jedince tvoří několika faktorů, viz graf č. 2 (Jansa a kol., 2012):

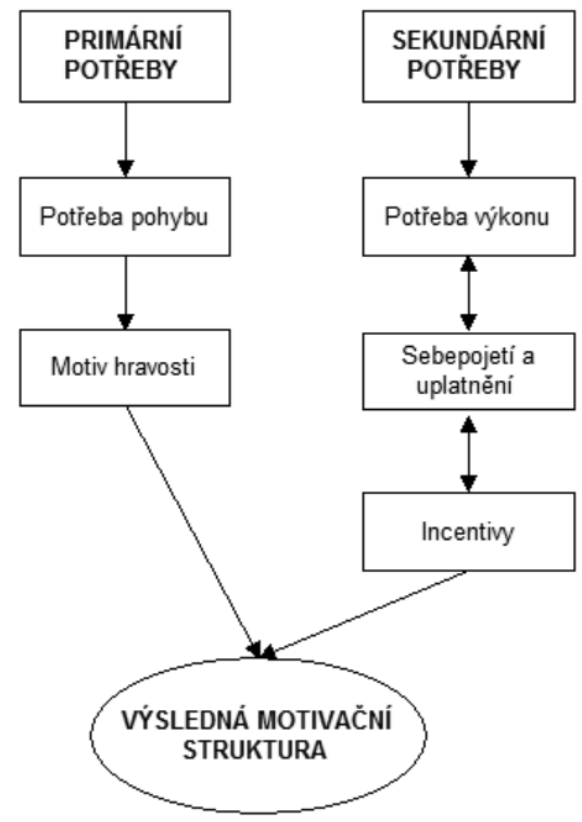

Obr. 2: Struktura motivačních tendencí (Pedagogika sportu, Jansa a kol., 2012)

Klíčovými prvky této struktury motivačních tendencí jsou především potřeba pohybu a motiv hravosti. A právě na tyto dva znaky by se trenéři nejmladších sportovců měli při stavbě tréninků soustředit. 
$\mathrm{S}$ přibývajícím věkem dětí lze zaznamenat jejich rostoucí autonomii. Je důležitá $\mathrm{k}$ regulaci jejich chování a určování směru, kterým se bude jedinec ubírat v souvislosti se svými činy. Při přechodu do školy děti často naráží na nesoulad mezi výchovou doma a ve školním prostředím, respektive mezi reakcemi rodičů na své činy a způsobem řešení situací ve škole. Školní prostředí, co se týče rozvoje autonomie, totiž může na dítě působit někdy podpůrně, jindy zcela opačně. Nekončící kontrola a zasahování do všech činností ze strany školy snižuje míru kontroly jedince při jeho vlastním jednání, což má za následek snížení zodpovědnosti v budoucích letech. Naopak učení se způsobem podporujícím autonomní chování vzbuzuje v dětech pocit odhodlání, a často také vyústuje v lepši pochopení (Deci \& Ryan, 1987). Mít vliv na průběh tréninkové jednotky a možnost volby by pro sportující dítě mohl být jeden ze způsobů, jak své autonomie dosáhnout.

Závěrem této kapitoly je třeba poznamenat, že všechny děti mají při svém narození stejnou dávku motivace (v př́padě dobrého zdravotního stavu), nicméně ta je v pozdějších letech ovlivněna tím, co se dětem stane v průběhu jejich života (Carlton \& Winsler, 1998) a jak jsou jejich osobnosti ovlivňovány a záměrně či bezděčně formovány.

\title{
4 METODY VEDOUCÍ KE ZVÝŠENÍ SPOKOJENOSTI Z ÚČASTI NA SPORTOVNÍM TRÉNINKU
}

Jak už bylo řečeno, ke každé věkové skupině by se nejen při prohlubování motivace a následně i adherence $\mathrm{v}$ rámci pohybových aktivit mělo přistupovat odlišně. Mělo by se užívat takových tréninkových a komunikačních postupů a metod, které nejen co nejefektivněji rozvinou pohybové schopnosti a dovednosti jedince, ale především prohloubí, respektive nepotlačí jeho vnitřní motivaci k participaci na těchto aktivitách.

\begin{abstract}
„Vyučovací metoda je pedagogická specificky didaktická aktivita subjektu a objektu vyučování, rozvíjející vzdělanostní profil žáka, současně působicí výchovnè, a to ve smyslu vzdèlávacích a také výchovných cílu a v souladu s vyučovacími a výchovnými principy. Spočívá v úpravě obsahu, v usměrňování aktivity objektu a subjektu, v úpravě zdrojů poznání, postupu a technik, v zajištěni fixace nebo kontroly vědomostí a dovedností, zájmů a postojü “ (Mojžíšek, 1977, s. 16; in Jansa a kol., 2012).
\end{abstract}

\section{- Možnost volby a kontroly nad průběhem aktivity}

Jedním ze základních aspektů zaručujících u dětí školního věku zvýšení vnitřní motivace je disponování možností volby, respektive pocitem kontroly nad průběhem aktivity. Výsledky studie (Alderman, Beighle \& Pangrazi, 2006) provedené na toto téma potvrzují následující: Studenti, kteří si mohli vybrat z více možností pohybových aktivit, byli mnohem více motivováni k provozování dané aktivity než ti, kteří $\mathrm{k}$ ní byli v podstatě donuceni, protože na výběr neměli. V praxi pak lze tato fakta uplatnit způsobem, kdy dětem, které jsou již zapojeny do praktikování určitého sportu, dáme coby trenéři možnost volby např. jednoho cvičení během tréninkové jednotky. Nejen na základě již zmíněných výzkumů, ale také z vlastní zkušenosti lze podotknout, že děti cvičení jednak více baví, ale také se více snaží, a především se cítí být zapojeni do samotné tvorby tréninkové jednotky, čímž se díky kontrole nad dějem zvyšuje také jejich sebevědomí. Teorii o možnosti výběru cvičení v rámci tréninkové jednotky a následném zvýšení vnitřní motivace potvrzuje výzkum Pangraziho (2001), který hráčům ledního hokeje nabídl možnost trénovat střelu dvěma způsoby, načež zaznamenal mnohem větší úsilí při trénování určitého druhu střelby, když si jej hráči mohli vybrat. 


\section{- ,No mistake' zone}

Neméně důležitým prvkem, který by měli trenéři do svých tréninkových jednotek zavést, je tzv. ,no-mistake‘ zone. Chyby či porážky provázejí každého sportovce nejen při výkonu jeho pohybové aktivity, ale také v životě jako takovém. Způsob, jak se s chybami a porážkami vypořádat, který trenér svým svěřencům předá, bude mít tedy dopad nejen na jejich prrípadnou reakci v rámci daného sportu, ale rovněž v životě obecně. $Z$ již dříve zmíněných studií je jasné, že vnitřní motivace je ovlivňována především spokojeností dítěte s tréninky, a stejně jako je důležité tuto spokojenost vytvářet, je důležité ji ani nepotlačovat. Proto by mělo být povinností trenéra usilujícího o nepotlačování pozitivních prožitků dětí, vysvětlit jim, že chyby, kterých se dopustí, respektive prohry, které zažijí, jsou něčím přirozeným a pro vývoj v podstatě nezbytným. Metodou ,no-mistake zone' se samozřejmě nenabádá k pochvale za chyby a zažité porážky, ale k reálnému vysvětlení těchto pojmů dětem, aby na ně v př́ště zareagovaly způsobem, který bude spiše snahou svou chybu odstranit. A po odstranění chyby je dovést ke zjištění, že právě díky uvědomění si této chyby se stali lepšími a měli co odstraňovat, respektive napravovat. Skutečnost uvědomění si, že jedinec dokázal něco, co předtím nezvládl, může na základě studie Ryana, Fredericka, Lepese, Rubia a Sheldona (1997) překlenout převahu vnější motivace ve prospěch vnitřní.

\section{- Žebřík neustále rostoucí obtížnosti výzev}

$Z$ výsledků naposledy zmíněné studie lze rovněž vyvodit, že je z trenérského pohledu velmi důležité zvyšovat objem, intenzitu či obtížnost cvičení a soutěžení tak, aby se dítě postupem času nezačalo nudit stále stejnou obtižností. Tento faktor nazvaný žebřík neustále rostoucí obtižnosti výzev zmínili ve svém výzkumu Csikszentmihalyi a Larson, (1984) a Nakamura a Csikszentmihalyi (2009). Důvod pro jeho aplikaci je očividný: Pokud se lidé budou stále snažit dosáhnout stejných úspěchů, které již zaznamenali, začne je jejich úsilí po určitém čase nudit.

\section{- Způsob ukončení tréninkové jednotky}

Na základě výzkumu psychologa Daniela Kahnemana lze předpokládat, že by i pouhou změnou ukončení tréninku mohlo být dosaženo jak zakomponování účelných cvičení (drillových, fyzicky náročnějších a nikterak oblíbených, avšak pro progres hráče nutných), tak také celkové spokojenosti mladého sportovce s tréninky. Studie zveřejněná v publikaci Myšlení, pomalé a rychlé (Kahneman, 2011) potvrzuje fungování teorie ,peak end', tedy že není důležitá celková bolest z nějaké nepř́jemné zkušenosti, ale samotný závěr této zkušenosti, respektive vzpomínka, kterou si jedinec odnese jako poslední. Níže uvedené grafy zobrazují profily prožitků dvou pacientů, kteří podstoupili kolonoskopické vyšetření. Pacienti během tohoto vyšetření měli každých šedesát vteřin označit, jakou úroveň bolesti v právě probíhajícím momentě pocitují, přičemž 0 znamená „vůbec žádná bolest“ a 10 „nesnesitelná bolest“. 

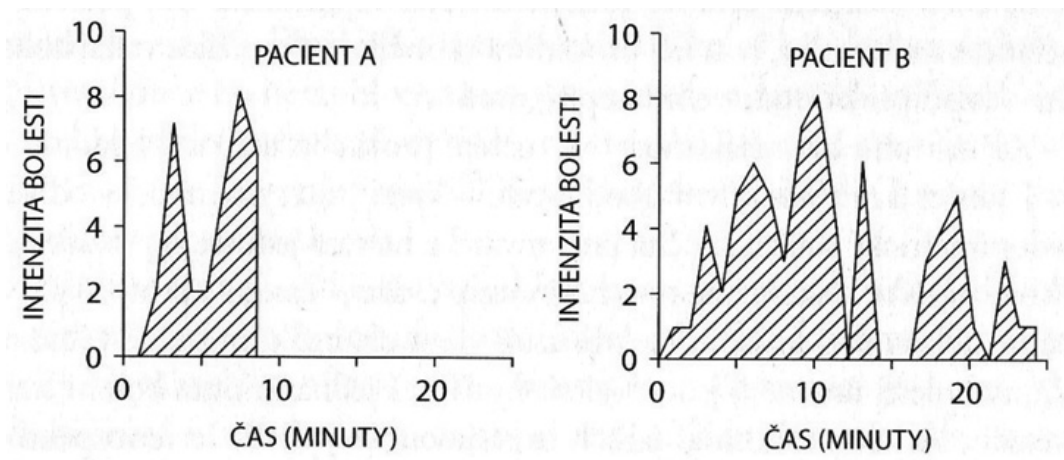

Obr. 3: Vývoj bolesti pacientů (Myšlení - rychlé a pomalé, Kahneman, D., 2011).

- Jak lze z grafu vyčíst, prožitek pacientů se během procedury výrazně měnil. Zatímco procedura pacienta A trvala osm minut, u pacienta B trvala minut čtyřiadvacet. Z letmého pohledu na grafy a především z obsahu „bolesti“ pod lomenou křivkou by mělo být zřejmě, že mnohem více trpěl pacient B. Klíčovým faktorem je pak pochopitelně fakt, že jemu trvala procedura mnohem déle. Pakliže ale budeme aplikovat již zmíněné pravidlo „peak-end“ na profily bolestí pacientů $\mathrm{A}$ a $\mathrm{B}$, jejichž nejhorší stav bolesti byl stejný - na hranici 8 - nicméně u pacienta A skončila procedura na stupni bolesti 7 a u pacienta B na stupni bolesti 1, zjistíme následující: Podle očekávání si pacient A uchoval na onu proceduru mnohem horší vzpomínku než pacient B (Kahneman, 2011). Byt tedy celková „bolest“ pod křivkou je o mnoho vyšší u pacienta B, odnáší si z dané procedury daleko méně nepř́ijemnou vzpomínku, než jakou si odnáší pacient A. A to pouze z důvodu „př́ijemnějšího“ ukončení procedury ${ }^{1}$. V praxi lze tyto poznatky využít například tak, že po náročném tréninku použijeme na jeho samém konci cvičení dětmi oblíbené.

\section{- Efektivní slovní působení z hlediska psychologického}

Poskytnout cvičenci výzvu správným slovním působením je dalším klíčovým faktorem při rozvoji vnitřní motivace. Existuje řada trenérů, kteří při komunikaci s dětmi mladšího školního věku a při výkladu určitého cvičení užívají výhradně formu direktivní. Čímž sice možná dosáhnou kýženého výsledku a cvičenci opravdu pohybový úkon správně splní, ale direktivní formou komunikace potlačí veškerou touhu, zábavnost a prostor pro kreativitu (Koestner, Ryan, Bernieri \& Holt, 1984). Je samozřejmé, že s postupujícím věkem by se zvyšováním autority trenéra měla direktivní složka převládat, tak by tomu však u dětí mladšího školního věku být nemělo (například u sportovní přípravky). Jedním z příkladů, jak u dětí zvýšit soutěživost a touhu dokázat něco samy sobě, je namísto direktivních př́stupů při komunikaci (Nyní budete minutu dělat..., Desetkrát co nejrychleji doběhněte tam a zpátky) či pouhého uživání slov jako měl bys či musís,, uživat mnohem efektivnější a k soutěživosti vedoucí formu jako je např.: Kdo za minutu dokáže vícekrát...?, Kdo udělá deset nejrychlejších přeběhů? apod. Obdobný případ může nastat v situaci, kdy trenér uvidí jedince perfektně zvládnout určitý pohybový úkon, načež jej v domnění, že jej chválí, nutí daný pohybový úkon direktivním stylem demonstrovat před zbytkem týmu. Ne všem dětem na psychiku pozitivně působí povinnost něco předvádět před zbytkem týmu, nicméně slovy „Chceš ukázat i ostatním, jak ti to jde?“ alespoň trochu zbavíme jedince stresu (Alderman, Beighle \& Pangrazi, 2006). Deci a kol. (1994) ve své studii zaměřené na internalizaci vnějších pobídek užili v případě, kdy si dítě nerado uklízí pokoj, jako př́klad následující výrok: Pokud si začneš uklizet pokoj, už nikdy své hračky neztratišs, ani si je nerozbiješ tím, že na ně omylem šlápneš.

\footnotetext{
${ }^{1}$ Tuto teorii potvrzují i doposud nepublikované výsledky A. Blažeje, který celý koncept výzkumu D. Kahnemana zasadil do sportovního prostředí.
} 
Pochopitelně se nelze spoléhat, že pouhými výroky se překlene motivace z vnější na vnitřní, nicméně takto alespoň dosáhneme jistého konfliktu mezi oběma fázemi motivace.

\section{- Imaginace}

Byt imaginace na první pohled nikterak zásadně nezasahuje do prohlubování pozitivních prožitků výhradně ze sportovních tréninků, na rozvoj interní motivace má významný dopad. Významný dopad má především z toho důvodu, že lidská mysl nezná rozdíl mezi skutečností a velmi intenzivně prožitou představou. Proto je při této metodě nejefektivnější představovat si úspěchy či aktivity své budoucího já co nejrealističtěji. Výsledky studie Sheldona a Lyubomirského (2006) potvrdily fakt, že praktikování tzv. vizualizačního cvičení best possible selves (BPS) je velmi účinné pro zvýšení a udržení pozitivní nálady a dosažení nejvyššího stupně motivace k př́slušné aktivitě. Při aplikaci do praxe však netřeba děti nabádat, aby si každý den samy sebe představovaly jako úspěšné sportovce, nicméně úlohou trenéra by mělo být jim alespoň připomínat, které zápasy či závody je čekají a co je v př́ípadě úspěchu nemine, včetně pocitu naplnění z potenciálního úspěchu. Je jen na každém trenérovi, jak s těmito fakty naloží, nicméně schopnost probudit $\mathrm{v}$ dětech představy o sobě samých na sportovním poli by mohlo být minimálně z hlediska prohlubování vnitřní motivace velmi efektivní.

I přes tyto pozitivní vlivy je imaginace nejvíce využívána na poli zvyšování motorických dovedností (Morris, Spittle \& Watt, 2005). Způsob, jakým imaginace funguje a proč je tak účinná při osvojování motorických dovedností, vysvětluje Carpenterova nervosvalová teorie (1984; in Weinberg \& Gould, 2011). Podle této teorie funguje imaginace na základě vytváření neurosvalových spojů pro motorickou činnost mozku. Při dobře provedené imaginaci se totiž v mozku zapojují stejná centra jako při reálném provedení úkonu, pouze v menší míře (Vičar, 2016).

\section{- Poskytnutí vzorů, u nichž je očividný progres}

Poskytnutí vzorů a prríkladů lidí, u nichž je očividný progres v určité aktivitě i přes počáteční neúspěch, je další důležitou komponentou v celkovém schématu rozvoje vnitřní motivace nejen u dětí. Studie Kitsantase, Zimmermana a Clearyho (2000), jež pozorovala změnu vnitřní motivace u dívek ve věku 14-16 let, potvrdila následující fakt: Dívky, které sledovaly jedince bezchybně trefujícího v šipkách patnáctkrát po sobě terč, nezaznamenaly v oblasti vnitřní motivace takový progres, jaký zaznamenaly dívky sledující jedince, který se před jejich očima ve stejné činnosti v porovnání s prvními pokusy zlepšil. Dívky, které sledovaly osobu, která ve zmíněné činnosti zaznamenala progres, byly tedy následně samy ochotnější a schopnější upravit svou dovednost v házení šipek. Studie potvrdila, že za zlepšením schopností a dovedností stojí mimo jiné také mentální proces (Larson \& Rusk, 2011). Minimálně poukazování na to, co kdysi svěřenci coby menší děti nedokázaly, a nyní už zvládnou, by rovněž mohlo mít vliv na potřebu se neustále zlepšovat.

\section{- Nepotlačování vnitřní motivace}

Ze zmíněných výsledků výzkumu Carltona a Winslera (1998) je známo, že děti coby lidské bytosti mají při absenci nemocí a chorob stejnou dávku motivace. $Z$ toho vyplývá, že by středem zájmu trenérů a učitelů tělesné výchovy neměla být pouze snaha vnitřní motivaci prohloubit, nýbrž také ji u dětí nepotlačovat. Už ze samé podstaty lidského bytí, s těmito teoriemi přišel například už Aristoteles, je pohyb jednou ze základních potřeb každého člověka a skutečnost, že někdo nechce prostřednictvím sportovních aktivit tuto potřebu uspokojovat, naznačuje, že je minimálně s motivy jedince něco v nepořádku. Podle teorie kognitivního hodnocení, kterou formulovali Deci a Ryan (1985), může použití vnějších odměn oslabit vnitřní motivaci, která potlačí zájem o práci samotnou. S odkazem na provedený výzkum Deci a Ryan uvedli: $K d y z ̌$ 
se odměny vyplácejí podobně, jako se poskytuje zpětná vazba, aby lidem vyjádřily uznání za dobre odvedenou práci, jsou proživány spontánně a budou vnitřní motivaci udržovat nebo posilovat. Když se ale odměny vyplácejí, aby lidi motivovaly, jsou prožívány nucenè a budou vnitřní motivaci oslabovat (Armstrong \& Taylor, 2015). Z toho lze usuzovat, že vnější a vnitřní komponenty motivace nejsou tzv. antagonisté, ale že naopak spolu koexistují, a tedy že doplnění motivačního schématu jedince vnějšími pobídkami vnitřní motivaci spíše zvýší, než sníží (Hayamizu, 1997). Obecně se však uvádí, že peníze coby vnější motiv vnitřní motivaci potlačují (pakliže nejsou vypláceny spontánně), zatímco pozitivní slovní pobídka (rovněž vnější motiv), ji může prohloubit (Deci \& Cascio, 1972)2. Podle studie, kterou provedli D. Harris a B. Harris (1984), se míra odhodlání sportovce může zvýšit také v případě, kdy za své úsilí, investovaný čas a celkovou obět', kterou svým počínáním přinesl, bude veřejně oceněn - tedy že jeho počínání podléhá kontrole a má pozitivní zpětnou vazbou na okolí (Vičar, 2016).

Možnosti trenéra jsou však v této oblasti značně omezené, protože s dětmi tráví mnohem více času rodiče a jejich přistup k odměňování je pro vývoj struktury motivačních tendencí jedince kruciální. Pokud bylo dítě celé své dětství hmotně motivováno, aby například doma pomohlo, stěží lze předpokládat, že by se u něj rozvinul smysl pro vykonání určité činnosti jen pro dobrý pocit. Tuto hypotézu potvrzuje výzkum Purcella-Gatese, Dukea a Martineaua (2007), kteří zkoumali vliv motivu na kvalitu brožur vyrobených dětmi. V tomto výzkumu měly v prvním případě děti brožury vyrábět pro místní přírodovědné centrum, ve druhém pouze pro známku v rámci výuky. Vyšší kvalita práce byla zjištěna u skupiny, jež vytvářela brožuru pro př́rodovědné centrum. Potlačená motivace $\mathrm{k}$ vykonávání pohybové aktivity je však $\mathrm{v}$ řadě případů způsobená nesprávným přístupem učitelů tělocviku a trenérů úplně nejmladších dětí, jimž vštěpují zvyk, že pohyb je něco, co dělat musí (pro známku, atraktivitu či jiný vnější motiv), a ne něco, co dělat chtějí na základě hlubšího motivu a uspokojení jedné z hlavních fyziologických potřeb.

\section{SHRNUTÍ}

Následující tabulka je krátkým souhrnem všech výše popsaných metod a principů, na jejichž aplikaci do svých tréninkových metod by neměli trenéři zapomínat. Je samozřejmé, že některé metody lze využít pouze u těch nejmladších, nebo naopak pouze u dětí staršího školního věku, nicméně $v$ případě jisté transformace by se určitě našel způsob, jak je užít $\mathrm{i} v$ jiných věkových kategoriích, než pro kterou jsou primárně určeny.

\footnotetext{
${ }^{2}$ Stejní autoři tvrdí, že i negativní zpětná vazba může mít pozitivní dopad na vnitřní motivaci, a to v tom smyslu, že bude působit vyzývavě. I zde se však musí respektovat určité hranice - tedy nesmí být například vyřknuta ponižující formou. Na základě svých výsledků a následných spekulací dodávají, že negativní zpětná vazba funguje ve vztahu k vnitřní motivaci jako křivka „převráceného U“.
} 


\begin{tabular}{|c|c|c|}
\hline Metoda & Popis & Příklady a poznámky \\
\hline $\begin{array}{l}\text { Možnost volby a kontroly } \\
\text { nad průběhem aktivity }\end{array}$ & $\begin{array}{l}\text { Během tréninkového procesu umožnit dětem volbu } \\
\text { nějakého cvičení. }\end{array}$ & $\begin{array}{l}\text { Například dítěti, které se v předcházejícím cvičení nejví- } \\
\text { ce snažilo, umožnit volbu dalšího, byt' krátkého, cvičení. }\end{array}$ \\
\hline ,No-mistake'zone & $\begin{array}{l}\text { Vytvořit na trénincích takové prostředí, v nichž se dítě } \\
\text { nebude bát chybovat. }\end{array}$ & $\begin{array}{l}\text { Neustále dětem připomínat, že pouze díky chybám } \\
\text { a jejich následnému napravování se zlepšují. }\end{array}$ \\
\hline $\begin{array}{l}\text { Žebřík neustále rostoucí } \\
\text { obtižnosti výzev }\end{array}$ & $\begin{array}{l}\text { Stavění tréninkových jednotek způsobem, při kterém } \\
\text { budou jednotlivá cvičení stále náročnější (přesto však } \\
\text { pro děti vykonatelná). }\end{array}$ & $\begin{array}{l}\text { Nemusí se jednat pouze o zvýšení náročnosti cvičení, } \\
\text { ale také o zvýšení objemu (opakování) nebo intenzity. }\end{array}$ \\
\hline $\begin{array}{l}\text { Pozitivnízpůsob } \\
\text { ukončení tréninku }\end{array}$ & $\begin{array}{l}\text { At' už byl trénink jakkoliv náročný, z jeho konce by si děti } \\
\text { měly odnést pozitivní vzpomínku. }\end{array}$ & $\begin{array}{l}\text { Napřílad užití zábavného a dětmi oblíbeného cvičení } \\
\text { na samém konci tréninku. }\end{array}$ \\
\hline $\begin{array}{l}\text { Efektivní slovní působení } \\
\text { z hlediska psychologického }\end{array}$ & $\begin{array}{l}\text { Použivání takových komunikačních metod, které vzbu- } \\
\text { dí v dětech soutěživost (včetně soutěžení se sebou } \\
\text { samotným), sniží stres či podpoři internalizaci vnějších } \\
\text { pobídek. } \\
\text { Vyvarovat se pokynů,musí̌s', měl bys' atp. }\end{array}$ & $\begin{array}{l}\text { „Kdo za minutu dokáže nejvice-krát...?", } \\
\text { „Kdo udělá deset nejrychlejších přeběhư?" } \\
\text { "Chceš ukázat i ostatním, jak ti to jde?" } \\
\text { „O kolik ses zlepšil v porovnánís minulým týdnem?" }\end{array}$ \\
\hline Imaginace & Využívání různých vizualizačních cvičení a představ. & $\begin{array}{l}\text { Co nejživěji dětem popisovat, co všechno budou umět } \\
\text { a jaké zápasy a úspěchy je čekají. } \\
\text { Vyspělejším dětem a mládeži vysvětlit, že imaginace } \\
\text { je velmi účinnou metodou při osvojování motorických } \\
\text { dovedností. }\end{array}$ \\
\hline $\begin{array}{l}\text { Poskytnutí vzorů, } \\
\text { u nichžje očividný progres }\end{array}$ & $\begin{array}{l}\text { Upozorňovat různými způsoby jak na progres samot- } \\
\text { ných dětí, tak také na progres jiných sportovců (např. } \\
\text { profesionálů). }\end{array}$ & $\begin{array}{l}\text { Setkání s osobnostmi daného sportu (například jejich } \\
\text { přednášky, kde popisují svůj pokrok). } \\
\text { V dnešní době mohou dobře posloužit videa a před- } \\
\text { nášky sportovců, sportovních událostí na internetu } \\
\text { (Youtube, TED...). }\end{array}$ \\
\hline $\begin{array}{l}\text { Nepotlačování } \\
\text { vnitřní motivace }\end{array}$ & $\begin{array}{l}\text { Hmotně děti odměňovat pouze minimálně. Pouze } \\
\text { tehdy, kdy si to po velké snaze opravdu zaslouží - tedy } \\
\text { spontánním způsobem. } \\
\text { Preferování morálních odměn. }\end{array}$ & $\begin{array}{l}\text { Např. posun v žebříčku v rámci určité dovednosti } \\
\text { na webových stránkách klubu či na nástěnce. }\end{array}$ \\
\hline
\end{tabular}

\section{ZÁVĚR}

Existuje několik vědecky potvrzených technik více či méně prohlubujících vnitřní motivaci, respektive zamezujících jejímu potlačování, které lze využít v oblasti sportovních aktivit dětí školního věku. Dủležitým aspektem při práci s vnitřní motivací není uspokojení z využívání pouze jedné, nýbrž nutnost pracovat s co nejvíce metodami, jelikož se jedná o souhru hned několika faktorů. Řada z nich je efektivní z toho důvodu, nebot pracuje se spokojeností a pozitivními prožitky, jejichž dosahování by mělo být u dětí školního věku primárním cílem. Tento článek a jeho doporučení by pak měly sloužit jako souhrn dalších možností, jak má trenér stavět tréninkové jednotky s ohledem na psychologii a jak přistupovat $\mathrm{k}$ dětem, co se týče komunikace. Jejich užití může alespoň částečně odstranit negativní vlivy osobnosti trenéra, kterou trenéři sami leckdy nemohou nijak napravit. Také je třeba mít na paměti, že děti by opravdu měly dělat pouze ty aktivity, které je baví, a po většinu času by se do nich neměly nutit. Pokud se budou pohybovat pouze v takovém prostředí a navštěvovat takové kroužky a sportovní aktivity, které je chtějí, budou vykazovat také nejvyšší stupeň pozitivních emocí, větší zapálení a větší pocit zadostiučinění z práce samotné (Deci, Vallerand, Pelletier \& Ryan, 1991). Tedy všechny znaky vyhledávané vnitřní motivace, která není ceněná pro emoční stav jako takový, ale pro dalekosáhlé pozitivní budoucí důsledky, které se na ni vážou. 


\section{Literatura}

Alderman, B., Beighle, A. \& Pangrazi, R. (2006). Enhancing motivation in physical education. JOPERD, volume 77, No. 2.

Armstrong, A. \& Taylor, S. (2015). Řizení lidských zdrojů; moderní pojetí a postupy. 13. vydání, Grada, ISBN 978-80-247-9883-7.

Carlton, M. \& Winsler, A. (1998). Fostering Intrinsic Motivation in Early Childhood Classrooms. Early Childhood Education Journal. Vol. 25, No. 3.

Csikszentmihalyi, M., \& Larson, R. (1984). Being adolescent. New York: Basic Books.

Deci, E. (1971). Effects of Externally Mediated Rewards on Intristic Motivation. University of Rochester, Journal of Personality and Social Psychology, vol. 18.

Deci, E. \& Cascio, W. (1972). Changes in Intristic Motivation as Function of Negative Feedback and Threats. Paper presented at Eastern Psychological Association Meeting, Boston.

Deci, E. L \& Ryan, R. (1985). Intrinsic motivation and self-determination in human behavior. New York: Plenum.

Deci, E. L \& Ryan, R. (1987) The support of autonomy and the control of behavior. Journal of Personality and Social Psychology, 53, 1024-1037.

Deci, E., Vallerand, R., Pelletier, L. \& Ryan, R. (1991). Motivation and Education: The Self-determination perspective. Educational Psychologist, p. 325-246.

Deci, E., Eghrari, H., Patrick, C. \& Leone, D. (1994). Facilitating Internalization: The Self-determination Theory Perspective. Journal of Personality.

Hanin, Y. (2007) Emotions in Sport: Current Issues and Perspectives. Handbook of Sport Psychology, 3rd ed. (pp. 31-58).

Hayamizu, T. (1997). Between intrinsic and extrinsic motivation: Examination of reasons for academic study based on the theory of internalization, 98-108.

Hošek, V., Slepička, P., Hátlová B. (2006). Psychologie sportu. Praha: Karolinum, ISBN 80-246-1290-9.

Kahneman, D. (2011). Myšlení - rychlé a pomalé. Brno: Jan Melvil Publishing, s. r. o., ISBN 978-80-87270-42-4.

Kenrick, D., Griskevicius, V., Neuberg, S. \& Schaller, M. (2010). Renovating the Pyramid of Needs: Contemporary Extensions Built Upon Ancient Foundations. Perspectives on Psychological Science. 292-314.

Kitsantas, A., Zimmerman, B., \& Cleary, T. (2000). The role of observation and emulation in the development of athletic self-regulation. Journal of Educational Psychology, 91, 241-250.

Koestner, R., Ryan, R., Bernieri, F. \& Holt, K. (1984). Setting limits on children's behavior: The differential effects of controling vs. informational styles on intristic motivation and creativity. Journal of personality.

Jansa, P. \& kol. (2012). Pedagogika sportu. Univerzita Karlova v Praze, nakladatelství Karolinum, Praha. ISBN 978 80-246-2026-8.

Juřinová, I., Stejskal, F. (1987). Rozvoj pohybových schopností ve školní tělesné výchově. Určeno pro posl. fakulty tělesné výchovy a sportu. 1. vyd. Praha: SPN, 202 s.

Larson, R. \& Rusk, N., (2011). Intrinsic Motivation and Positive Development. Advances in Child Development and Behavior, Vol. 41, Burlington: Academic Press, pp. 89-130. ISBN: 978-0-12-386492-5.

Morris, T. Spittle, M. \& Watt, A. P. (2005). Imagery in sport. Champaing: Human Kinetics.

Nakamura, J., \& Csikszentmihalyi, M. (2009). Flow theory and research. In C. R. Snyder \& S. J. Lopez (Eds.), Handbook of positive psychology. (2nd ed., pp. 195-206). New York: Oxford.

Nakonečný, M. (1999). Sociální psychologie. Academia, ISBN 80-200-0690-7.

Nawijn, J., Marchand, M., Veenhoven, R. \& Vingerhoets, J. (2010). Vacationers Happier, but Most not Happier After a Holiday. Applied Research in Quality of Life, Volume 5.

Pano, G. \& Marcola, L. (2012). 14-18 years old children attitudes, perception and motivation towards extra curricular physical activity and sport. Journal of Human Sport and Exercise. ISSN 1988-5202.

Purcell-Gates, V., Duke, N., \& Martineau, J. (2007). Learning to read and write genre-specific text: Roles of authentic experience and explicit teaching. Reading Research Quarterly, 42, 8-45.

Ryan, R. \& Deci, R. (2000). Intrinsic and Extrinsic Motivations: Classic Definitions and New Directions. University of Rochester. Contemporary Educational Psychology.

Ryan, R., Frederick, C., Lepes, D., Rubio, N. \& Sheldon, K. (1997). Intrinsic Motivation and Excercise Adherence. Journal of Sport Psychology, p. 335-354.

Seligman, M. (2002). Authentic Happiness: Using the New Positive Psychology to Realize Your Potential for Lasting Fulfillment. Free Press, New York, ISBN 978-0-7432-2297-6.

Sheldon, K. \& Lyubomirsky, S. (2006). How to increase and sustain positive emotion: The effects of expressing gratitude and visualizing best possible selves. The Journal of Positive Psychology, p. 73-82.

Slaměník, I. (2011). Emoce a interpersonální vztahy. Grada Publishing, a.s. ISBN 978-80-247-7452-7.

Stuchlíková, I. (2007). Základy psychologie emocí. Vyd. 2., Praha: Portál, ISBN 978-80-7367-282-9.

Suchomel, A. (2004). Somatická charakteristika dètí školního věku s rozdílnou úrovní motorické výkonnosti. Vyd. 1. Liberec: Technická univerzita v Liberci, 140 s. ISBN 80-708-3900-7.

Válková, H. (2016). Představení „teorie transition”. Článek prezentován v přednášce při 7. ročníku odborné mezinárodní konference Psychologie sportu v praxi 2016 aneb Sport - průvodce životem.

Vágnerová, M. (2005). Základy psychologie. Univerzita Karlova v Praze, Nakladatelství Karolinum. ISBN 80-246-0841-3.

Vičar, M. (2016). Ottawský dotazník mentálních dovedností ve sportu - uživatelský manuál pro konzultanty a sportovní psychology OMSTAT - 3* - modifikovaná verze. Masarykova univerzita v Brně. 
Wylleman, P., Lavallee, D. \& Alfermann, D. (1999). Career Transitions in Competitive Sports. FEPSAC Monograph Series. ISSN $1562-1278$

Zacharová, E. (2012). Základy vývojové psychologie. Ostravská univerzita v Ostravě. ISBN 978-80-7464-220-3.

\section{Korespondující autor:}

Mgr. Adam Blažej, 429411@mail.muni.cz 